\title{
KEBIJAKAN PEMERINTAH DAERAH DALAM PENANGANAN KEBAKARAN LAHAN DI KOTA PALANGKA RAYA
}

\author{
Andry Heriady
}

\begin{abstract}
ABSTRAK
Kebakaran hutan dan lahan di Wilayah Kota Palangka Raya memang sudah di klasifikasikan sebagai bencana alam musiman oleh Pemerintah Daerah Kota Palangka Raya kerena selalu terjadi setiap tahunnya, dengan hal ini perlu perhatian khusus dari Pemerintah Daerah Kota Palangka Raya melalui Dinas Kehutanan dan Perkebunan Kota Palangka Raya terhadap penanganannya agar dampak kesehatan, lingkungan, ekonomi, hukum, sosial, dan politik yang ditimbulkan bisa berkurang. Dan jika terdapat kendala dalam pelaksanaan penanganan kebakaran hutan dan lahan maka Pemerintah Daerah Kota Palangka Raya diberikan wewenang untuk memecahkan permasalahan ini bersama-sama dengan pihak lain yang juga ikut serta dalam penanganan permasalahan ini. Pelaksanaan kebijakan yang dikeluarkan oleh Pemerintah tentu akan menghadapi suatu kendala dalam pelaksanaannya, namun jika suatu kebijakan ingin berjalan dengan baik maka wajib memperhatikan beberapa unsur yaitu seperti Komunikasi, Sumber Daya ( sumber daya manusia, anggaran, fasilitas, serta informasi dan kewenangan ), Disposisi, dan Struktur Organisasi.

Dalam beberapa kebijakan yang telah dibuat selama ini oleh Pemerintah Daerah dalam penanganan kebakaran lahan di Kota Palangka Raya memang sudah cukup banyak, namun salah satu kendala yang telah dihadapi oleh Dinas Kehutanan dan Perkebunan selama ini yaitu dari faktor anggaran setiap tahunnya yang masih kurang serta partisipasi masyarakat yang kurang dalam proses pelaksananaan seluruh kebijakan-kebijakan yang telah diamanahkan oleh Pemerintah. Saran yang dikemukakan dalam penelitian ini adalah perlunya mempertikan keseimbangan kebijakan-kebijakan dengan faktor penunjangnya yaitu anggaran yang tersedia untuk penanganan permasalahan ini serta partisipasi masyarakat yang kurang aktif dalam proses pelaksanaan semua kebijakan yang telah ada.
\end{abstract}

Kata Kunci : Pemerintah, Kebijakan, Anggaran, Partisipasi Masyarakat.

\section{PENDAHULUAN}

\section{Latar Belakang}

Indonesia merupakan negara kepulauan yang memiliki lima pulau besar, oleh kerena itu tentu memiliki permasalahan bencana alam yang berbeda-beda pada setiap daerahnya, terutama disini masalah kebakaran lahan, kebakaran lahan memang sering terjadi di beberapa daerah di Indonesia setiap tahunnya, menurut Badan Nasional Penanggulangan Bencana (BNPB) khususnya di Kalimantan dan Sumatera, terdapat ratusan titik api (hotspot) kebakaran lahan muncul di kalimantan dan sumatera, dari pantauan satelit National Oceanic and Atmospheric Administration (NOAA) per September 2014, di Kalimantan Tengah ada (227) titik api, Kalimantan Barat (112), Kalimantan Selatan (39), Sumatera Selatan (134), Riau (89), dan Jambi (62).

Dilihat dari data yang dimiliki Badan Nasional Penanggulangan Bencana (BNPB) diatas bahwa Provinsi Kalimantan Tengah mempunyai titik api (hotspot) kebakaran lahan terbanyak dari beberapa daerah lainnya, berbicara mengenai kebakaran lahan di Kalimantan Tengah khususnya di Kota Palangka Raya juga ditemukan banyak titik api (hotspot) menurut bapak Sucipto salah satu petugas pemadam Kebakaran Kota Palangka Raya saat peneliti temui 
di tempat pada awal observasi lapangan, beberapa Kelurahan di Palangka Raya rata-rata semuanya terdapat titik api (hotspot).

Kebakaran lahan disebabkan oleh dua faktor pertama memang dari faktor alam dan kedua faktor manusia, penyebab dari faktor alam adalah ketika terjadinya kemarau yang sangat panjang maka di dalam tanah terjadinya gesekan benda-benda kering yang menimbulkan api kecil lalu semakin lama semakin besar ditambah Kota Palangka Raya merupakan tanah gambut dan jika musim kemarau akan mudah sekali terbakar dan merambat kesemua arah. Penyebab faktor manusia adalah pembakaran lahan secara sengaja hal ini terjadi saat penyiapan lahan untuk penanaman bibit pertanian, pembukaan lahan dengan membakar masih menjadi cara paling efektif bagi masyarakat dalam membuka lahan, serta kurangnya kesadaran masyarakat dengan membuang puntung rokok sembarang tempat.

Tanpa disadari kebakaran lahan merupakan salah satu penyebab kerusakan lahan yang paling besar dan bersifat sangat merugikan, serta kebakaran lahan menimbulkan kerugian secara kesehatan, ekonomi, pendidikan, serta lingkungan. Maka mulai akhir bulan Agustus sampai September 2014 Kota Palangka Raya dilanda kebakaran lahan, ditinjau dari data kesehatan menurut RSUD dr. Doris Sylvanus melalui Kalteng Pos sudah mengakibatkan 514 bayi menderita infeksi saluran pernapasan akut (ISPA) hingga ada beberapa bayi yang meninggal dunia, beberapa jadwal penerbangan dibatalkan kerena jarak pandang sangat rendah, aktifitas belajar mengajar juga terganggu dan tidak efektif, kerusakan lingkungan dimana-mana dan ekosistem di dalamnya menjadi tidak normal lagi.

Oleh kerena itu apakah produk politik Peraturan Daerah Kota Palangka Raya Nomor 07 Tahun 2003 Tentang Pencegahan dan Penanggulangan Kebakaran Hutan dan Lahan di wilayah Kota Palangka Raya selama ini yang dilaksanakan oleh Pemerintah melalui Dinas Kehutanan dan Perkebunan Kota Palangka Raya dalam penanganan kebakaran lahan apakah ada langkah-langkah pengendaliannya, misalkan sosialisasi, pemberdayaan masyarakatnya, pencegahan kebakaran lahan baik secara ekonomi dan teknologi, serta jalan keluar lainnya yang tepat dalam penanganan permasalahan kebakaran lahan yang terus terjadi setiap tahunnya.

Setelah beberapa bulan melaksanakan penelitian, peneliti menemukan beberapa hal yang membuat kenapa bencana alam kebakaran lahan di Kota Palangka Raya selalu terjadi setiap tahunnya walaupun kebijakan-kebijakan yang selama ini dibuat dalam rangka penanganan kebakaran lahan telah ada, dalam segi hirarki pemerintahan dari bagian teratas sampai bagian bawah komunikasi memang cukup baik di beberapa kecamatan sampai kelurahan terkait sosialisasi kebijakan-kebijakan yang selama ini di buat dalam pencegahan, pengendalian, penanganan, serta rehabilitasi akibat kebakaran lahan di Kota Palangka Raya namun juga disisi lain komunikasi kurang berjalan dengan baik didalam pelaksanaan kebijakan yang ada.

Faktor penghambat dalam pelaksaan kebijakan-kebijakan yang ada sudah cukup jelas di dalam penelitian ini terhadap penanganan kebakaran lahan di Kota Palangka Raya oleh Pemerintah Daerah, hal-hal utama faktor kendala di lapangan antara lain kurangnya anggaran setiap tahunnya yang diberikan Pemerintah Daerah kepada Dinas Kehutanan dan Perkebunan Kota Palangka Raya maka hal inilah yang menjadi faktor penghambat pertama dalam pelaksanaan kebijakan Pemerintah Daerah mengapa demikian tanpa anggaran pelaksanaan kebijakan untuk mengadakan acara sosialisai pencegahan, pengendalian, dan penanganan serta melengkapi sarana dan prasarana juga akan terbatas sebab anggaran kurang dan akibatnya penanganan kebakaran lahan juga tidak akan maksimal.

Serta peran masyarakat sangat kurang aktif dalam ikut serta menjalankan kebijakankebijakan yang telah dibuat oleh Pemerintah Daerah saat ini terlihat dari hasil wawancara langsung kepada masyarakat di beberapa kelurahan, disini dalam pelaksanaan kebijakan jika hanya satu pihak yang aktif maka permasalahan yang ada hanya akan berjalan di tempat dan 
tidak akan ada perubahan yang lebih baik akan terjadi dan pastinya akan tetap sama setiap tahun kedepan akan terjadi kebakaran lahan di wilayah Kota Palangka Raya dan dampak yang akan ditimbukan juga akan tetap sama.

Untuk itu kedepan sinergitas aktif dari Pemerintah Daerah bersama masyarakat Kota Palangka Raya sebenarnya di tingkatkan agar kebakaran lahan setiap tahun ini bisa berkurang dan dampaknya juga akan berkurang bagi masyarakat dan pada semua aspek kehidupan yang ada di dalamnya, dan Pemerintah Daerah melalui Dinas Kehutanan dan Perkebunan Kota Palangka Raya wajib lebih memperhatikan permasalahan bencana alam kebakaran lahan ini dan bagaimana solusi terbaik dalam penanganannya kedepan.

Harapan kita setelah kebijakan-kebijakan yang ada telah dibuat maka dari sinilah semua pihak wajib melaksanakan dan mentaatinya supaya bencana alam kebakaran lahan ini bisa teratasi dengan baik dan jika ada kekurangan dalam pelaksanaannya bisa diadakan evaluasi yang mendalam baik dari Pemerintah Pusat, Pemerintah Daerah, Dinas Kehutanan dan Perkebunan Kota Palangka Raya agar mengetahui apa saja hal yang menjadi faktor penghambat dalam pelaksanaan kebijakan-kebijakan tersebut di lapangan selama ini di Wilayah Kota Palangka Raya.

\section{Rumusan Masalah}

1. Bagaimana kebijakan Pemerintah Kota Palangka Raya dalam penanganan kebakaran lahan yang telah dilakukan oleh Dinas Kehutanan dan Perkebunan Kota Palangka Raya?

2. Apa saja faktor penghambat dan pendukung penanganan masalah kebakaran lahan oleh Dinas Kehutanan dan Perkebunan Kota Palangka Raya?

\section{Tujuan Penelitian}

1. Untuk mengetahui dan menganalisis kebijakan penanganan kebakaran lahan oleh Pemerintah khususnya Dinas Kehutanan dan Perkebunan Kota Palangka Raya.

2. Untuk mengetahui dan menganalisis faktor-faktor yang mempengaruhi Pemerintah khususnya Dinas Kehutanan dan Perkebunan Kota Palangka Raya dalam penanganan kebakaran lahan di Kota Palangka Raya.

\section{TINJAUAN PUSTAKA}

\section{Pemerintah Daerah}

Menurut Undang-Undang Otonomi Daerah Nomor 23 Tahun 2014 Tentang Pemerintahan Daerah tertuang pada Pasal 1 ayat (2) Pemerintahan daerah adalah penyelenggara urusan pemerintahan oleh pemerintah daerah dan dewan perwakilan rakyat daerah menurut asas otonomi dan tugas pembantuan dengan prinsip otonomi seluas-luasnya dalam sistem dan prinsip Negara Kesatuan Republik Indonesia sebagaimana dimaksud dalam Undang-Undang Dasar Negara Republik Indonesia Tahun 1945.

Menurut Undang-Undang Otonomi Daerah Nomor 23 Tahun 2014 Tentang Pemerintahan Daerah tertuang pada Pasal 1 ayat (3) Pemerintah daerah adalah kepala daerah sebagai unsur penyelenggara Pemerintahan Daerah yang memimpin pelaksanaan urusan pemerintahan yang menjadi kewenangan daerah otonom.

\section{Otonomi Daerah}

Menurut Undang-Undang Otonomi Daerah Nomor 23 Tahun 2014 Tentang Pemerintahan Daerah tertuang pada Pasal 1 ayat (6) Otonomi daerah adalah hak, wewenang, dan kewajiban daerah otonom untuk mengatur dan mengurus sendiri urusan pemerintahan dan kepentingan masyarakat setempat sesuai dalam sistem Negara Kesatuan Republik Indonesia. 
Menurut Undang-Undang Otonomi Daerah Nomor 23 Tahun 2014 Tentang Pemerintahan Daerah tertuang pada Pasal 1 ayat (7) Asas Otonomi adalah prinsip dasar penyelenggaraan Pemerintahan Daerah berdasarkan Otonomi Daerah.

Menurut Undang-Undang Otonomi Daerah Nomor 23 Tahun 2014 Tentang Pemerintahan Daerah tertuang pada Pasal 1 ayat (8) Desentralisasi adalah penyerahan Urusan Pemerintahan oleh Pemerintah Pusat kepada daerah otonom berdasarkan Asas Otonomi.

\section{Kewenangan Daerah}

Menurut Undang-Undang Otonomi Daerah Nomor 23 Tahun 2014 Tentang Pemerintahan Daerah tertuang pada Pasal 12 ayat (1) Urusan pemerintahan wajib yang berkaitan dengan pelayaran dasar sebagaimana dimaksud dalam pasal 11 ayat (2) meliputi poin $\mathrm{b}, \mathrm{e}, \mathrm{f}$, :

b. Kesehatan.

e. Ketentraman, ketertiban umum, dan perlindungan masyarakat.

f. Sosial

Menurut Undang-Undang Otonomi Daerah Nomor 23 Tahun 2014 Tentang Pemerintahan Daerah tertuang pada Pasal 12 ayat (2) Urusan pemerintahan wajib yang berkaitan dengan pelayaran dasar sebagaimana dimaksud dalam pasal 11 ayat (2) meliputi poin $\mathrm{e}, \mathrm{g}, \mathrm{p}$, :

e. Lingkungan hidup.

g. Pemberdayaan masyarakat desa.

p. Kebudayaan.

\section{Pengertian Kebijakan}

Kebijakan Publik merupakan suatu aturan-aturan yang dibuat oleh pemerintah dan merupakan bagian dari keputusan politik untuk mengatasi berbagai persoalan dan isu-isu yang ada dan berkembang di masyarakat, kebijakan publik juga merupakan keputusan yang dibuat oleh pemerintah untuk melakukan pilihan tindakan tertentu untuk tidak melakukan sesuatu maupun untuk melakukan tidakan tertentu. Dalam kehidupan masyarakat yang ada di wilayah hukum suatu negara sering terjadi berbagai permasalahan, negara yang memengang penuh tanggung jawab pada kehidupan rakyatnya harus mampu menyelesaikan permasalahanpermasalahan tersebut. Kebijakan publik yang dibuat dan dikeluarkan oleh negara diharapkan dapat menjadi solusi akan permasalahan-permasalahan tersebut. Kebijakan Publik adalah suatu keputusan yang dimaksudkan untuk tujuan mengatasi permasalahan yang muncul dalam suatu kegiatan tertentu yang dilakukan oleh instansi pemerintah dalam rangka penyelenggaraan pemerintahan (Mustopadidjaja, 2002).

\section{Jenis Kebijakan}

Kebijakan Publik di Indonesia dalam arti luas terbagi dua, yaitu kebijakan dalam bentuk peraturan-peraturan tertulis dan peraturan-peraturan tidak tertulis yang disepakati umum (konvensi). Kebijakan publik dibuat bermacam-macam bentuknya, antara lain sebagai berikut:

a. Peraturan Perundang-Undangan :

1. UUD 1945.

2. Undang-Undang atau Peraturan Pemerintah.

3. Peraturan Pemerintah.

4. Peraturan Presiden.

5. Peraturan Daerah.

b. Pidato Pejabat Tinggi :

1. Pidato presiden setiap tanggal 17 Agustus. 
2. Pidato presiden atau menteri pada waktu hari besar nasioanal.

3. Pernyataan pejabat Negara.

\section{Pengertian Kebakaran Lahan}

Kebakaran hutan dibedakan pengertiannya dengan kebakaran lahan, dimana perbedaannya terletak pada lokasi kejadiannya. Kebakaran hutan yaitu kebakaran yang terjadi di dalam kawasan hutan, sedangkan kebakaran lahan adalah kebakaran yang terjadi diluar kawasan hutan (Pubowaseso, 2004).

\section{METODE PENELITIAN}

Penelitian menggunakan penelitian kualitatif tipe deskriptif yaitu metode penelitian untuk membuat gambaran mengenai situsi atau kejadian (Nazir:2003). Tipe penelitian ini memberikan peluang yang besar akan munculnya interprestasi-interprestasi alternatif. Metode ini juga mampu mendekatkan antara peneliti dengan objek yang dikaji. Cara kerja proses penelitian ini berlangsung serempak dan dilakukan dalam bentuk pengumpulan.

Pengolahan data dengan menggunakan pendekatan. Menurut, namawi, penelitian deskriptif terbatas pada usaha mengungkapkan suatu masalah atau keadaan atau peristiwa sebagimana adanya sehingga bersifat sekedar untuk mengungkapkan fakta. Rakhmat (199:24) menyatakan bahwa penelitian deskriptif hanyalah memaparkan situasi atau peristiwa. Penelitian ini tidak mencari atau menjelaskan hubungan, tidak menguji hipotesis atau membuat prediksi. Penelitian ini ditujukan untuk mengumpulkan informasi secara aktual rinci yang menggambarkan gejala yang ada, mengidentifikasikan masalah atau memeriksa kondisi dan praktek-praktek yang berlaku, pendekatan kualitatif dilakukan untuk menghasilkan data yang luas dan mendalam.

\section{HASIL DAN PEMBAHASAN}

Kebijakan Pemerintah Daerah dalam Penanganan Kebakaran Lahan di Kota Palangka Raya antara lain melalui Peraturan Daerah Kota Palangka Raya bersama Dinas Kehutanan dan Perkebunan Kota Palangka Raya adalah sebagai berikut:

1. Pemerintah Daerah Kota Palangka Raya :

a. Peraturan Daerah Kota Palangka Raya Nomor 07 Tahun 2003 Tentang Pencegahan dan Penanggulangan Kebakaran Hutan dan Lahan di Wilayah Kota Palangka Raya.

b. Instruksi Walikota Palangka Raya Nomor : 611 Tahun 2014 Tentang Antisipasi Pencegahan Kebakaran Hutan dan Lahan di Kota Palangka Raya.

c. Keputusan Walikota Palangka Raya Nomor 394 Tahun 2014 Tentang Penetapan Status Tanggap Darurat Bencana Kebakaran Hutan, Lahan, dan Pekarangan serta Kabut Asap di Kota Palangka Raya Tahun 2014.

d. Keputusan Walikota Palangka Raya Nomor 27 Tahun 2014 Tentang Pembentukan Tim Koordinasi Pengendalian Kebakaran Hutan, Lahan, di Wilayah Kota Palangka Raya Tahun 2014.

e. Keputusan Walikota Palangka Raya Nomor 403 Tahun 2014 Tentang Penyelenggaraan Pos Komando Tanggap Darurat Bencana Kebakaran Hutan, Lahan, dan Pekarangan serta Kabut Asap di Kota Palangka Raya Tahun 2014.

2. Pemerintah Dinas Kehutanan dan Perekebunan Kota Palangka Raya :

a. Keputusan Kepala Dinas Kehutanan dan Perkebunan Kota Palangka Raya Nomor : 418.A Tahun 2014 Tentang Pembentukan Tim Pencegahan dan Pengendalian Kebakaran Hutan dan Lahan.

b. Himbauan Kepala Dinas Kehutanan dan Perkebunan Kota Palangka Raya Nomor : 522/DKP-KP/774/VII/2013 Tentang Larangan Pembakaran Hutan dan Lahan pada musim kemarau tahun 2013. 
c. Kesepekatan Bersama antara Kepala Dinas Kehutanan dan Perkebunan Kota Palangka Raya dengan Kepolisian Resor Palangka Raya Tentang Penggelaran PolMas sebagai BinMas Pionir, Nomor : 522.0/546/DKP-KP/01/V/2013 bersama Nomor : B/88/ /V/2013/POLRES.

d. Prosedur Tetap Operasional (protap) Pengendalian Kebakaran Hutan dan Lahan di Kota Palangka Raya.

\section{Implementasi Kebijakan (George C. Edward III) oleh Pemerintah Daerah Kota Palangka Raya:}

a. Komunikasi (Communication)

Mengenai hubungan komunikasi terkait kebijakan-kebijakan yang ada dalam penanganan kebakaran lahan di Kota Palangka Raya dari Pemerintan Daerah Kota Palangka Raya kepada Dinas Kehutanan dan Perkebunan Kota Palangka Raya sudah cukup baik selama ini, namun komunikasi selanjutnya kepada masyarakat Kota Palangka Raya terhadap sosialisasi suatu kebijakan-kebijakan yang telah dikeluarkan cukup rendah, mengapa demikian saat penulis mewawancarai masyarakat di beberapa kelurahan ada beberapa orang mengatakan sosialisasi mengenai himbauan hanya sampai di kelurahan namun tidak sampai di masyarakat bawah, namun juga ada beberapa masyarakat di kelurahan lain mengatakan komunikasi Pemerintah Daerah sudah ada yang memang sampai di masyarakat melalui blangko-blangko tentang himbauan larangan membakar lahan yang dibagikan kesetiap rumah masyarakat, selanjutnya spanduk juga sudah ada di pasang di tempat-tempat strategis di beberapa kelurahan. Jadi bisa kita simpulkan bahwa adanya sosialisasi yang terlaksana dengan baik dan juga ada yang memang kurang terlaksana dengan baik sesuai dengan beberapa kelurahan di atas, namun juga peran aktif masyarakat disetiap kelurahan juga sangat penting baik dari RT/RW memberikan informasi kepada masyarakat dan masyarakat lebih aktif dalam menjalankan semua kebijakan-kebijakan yang ada agar bencana alam kebakaran lahan di Kota Palangka Raya tidak terjadi dan bisa menekan rendah dampak kebakaran lahan.

b. Sumber Daya (Resources)

- Sumber Daya Manusia (Staff)

Dalam pelaksanaan kebijakan-kebijakan Pemerintah Daerah sumber daya manusia di Dinas Kehutanan dan Perkebunan Kota Palangka Raya memang cukup kurang hanya 15 personil yang penulis dapatkan pada kepala seksi perlindungan dan pengamanan hutan yang hal ini mempunyai tugas pokok dan fungsi menangani kebakaran lahan di Kota Palangka Raya selama ini, namun disini Dinas Kehutanan dan Perkebunan Kota Palangka Raya tidak merasa kesulitan dalam pelaksanaan pemadaman kerena dari Instruksi Walikota Palangka Raya melalui beberapa kebijakan-kebijakan yang dikeluarkan Dinas Kehutanan dan Perkebunan Kota Palangka Raya diperbantukan oleh beberapa Dinas, Badan, Lembaga, Organisasi, serta Masyarakat Kota Palangka Raya. Oleh kerena itu Dinas terkait jika selama ini masih kekurangan personil atau SDM menjadi lebih mudah kerena masih banyak pihak membantu dalam penanganan kebakaran lahan di Kota Palangka Raya selama ini.

- Anggaran (Budgetary)

Mengenai anggaran selama ini dalam pelaksanaan pencegahan, pengendalian, pengamanan, dan pemadaman kebakaran lahan di Kota Palangka Raya memang cukup 
kurang terlihat dari beberapa anggaran dari tahun 2013 (Rp. 72.000.000) serta penambahan anggaran pada tahun 2014 (Rp. 89.500.000) jadi penambahannya hanya beberapa juta rupiah. Dengan dana senilai ini untuk pencegahan, pengendalian, pengamanan, dan pemadaman kebakaran lahan di Kota Palangka Raya masih cukup kurang sekali dibandingkan dengan luas Wilayah Kota Palangka Raya seluas 2.678,51 Km2 (267,51 Ha) dibagi ke dalam 5 (lima) Kecamatan yaitu Kecamatan Pahandut 117,25 Km2, Sebangau 583,50 Km2, Jekan Raya 352,62 Km2, Bukit Batu 572 Km2, dan Rakumpit 1.053,14 Km2.

- Fasilitas (Facility)

Terkait fasilitas selama ini yang dimiliki oleh Dinas Kehutan dan Perkebunan Kota Palangka Raya memang cukup kurang juga terkendala dana yang ada juga menghambat penambahan fasilitas dalam pencegahan, pengendalian, pengamanan, dan pemadaman kebakaran lahan di Kota Palangka Raya juga terhambat lalu dalam penanganannya juga kurang maksimal di lapangan selama tahun 2014.

- Informasi dan Kewenangan (Information and Authority)

Mengenai pemberian informasi dan kewenangan sudah ada dijelaskan sebelumnya bahwa efektifitas pemberian informasi memang masih kurang efektif dari Pemerintah Kelurahan pada beberapa masyarakat di kelurahan yang ada dalam rangka pencegahan kebakaran hutan di Kota Palangka Raya melalui sosialisasi bebijakan-kebijakan yang ada hanya sampai pada beberapa pihak dan masih kurang sampai pada masyarakat terbawah di Wilayah Kota Palangka Raya. Dan mengenai kewenangan dalam penanganan kebakaran lahan di Kota Palangka Raya sudah cukup jelas melalui Pemerintah Daerah yaitu Dinas Kehutanan dan Perkebunan Kota Palangka Raya.

c. Disposisi (Disposition)

Dalam hal ini disposisi beberapa Pemerintah Kelurahan yang masih kurang dalam sosialisasi kebijakan-kebijakan berupa Peraturan Perundang-undangan, Peraturan Daerah, dan juga surat himbauan dari pihak terkait yang memiliki tugas pokok dan fungsi dalam penanganan kebakaran Lahan di Kota Palangka Raya terlihat dari hasil wawancara yang telah dilakukan oleh penulis pada penelitian ini beberapa bulan lalu di beberapa kelurahan di Kota Palangka Raya.

d. Struktur Birokrasi (Bereucratic Structure)

Mengenai struktur birokrasi dalam penanganan kebakaran lahan di Kota Palangka Raya saat ini cukup jelas kebijakan-kebijakan yang ada dibuat oleh Pemerintah Daerah Kota Palangka Raya dilimpahkan lagi kepada Dinas Kehutanan dan Perkebunan Kota Palangka Raya dan ditangani oleh Kepala Seksi Perlindungan dan Pengamanan Hutan yang hal ini memang memiliki tugas pokok dan fungsi sebagai pelaksana dilapangan selama ini, serta juga diperbantukan oleh pihak-pihak yang diberikan kewenangan oleh Walikota Palangka Raya.

\section{KESIMPULAN DAN SARAN}

\section{Kesimpulan}

Merujuk pada pokok permasalahan yang di angkat dan dianalisis yang telah dilakukan dalam tahapan-tahapan penelitian ini, dapat disimpulkan beberapa hal terkait Kebijakan Pemerintah Daerah dalam Penanganan Kebakaran Lahan di Kota Palangka Raya sebagai berikut : 
1. Pembuatan dan Sosialisasi kebijakan pencegahan dan penanganan kebakaran lahan.

2. Peningkatan penegakan hukum terhadap pelaku pembakaran lahan.

3. Pembentukan regu pemadaman hutan dan lahan secara dini.

4. Melakukan pengawasan terhadap pembukaan dan pembakaran lahan oleh masyarakat.

5. Menyediakan bibit tanaman dalam rangka tanaman dalam rangka rehabilitasi hutan dan lahan pasca kebakaran.

6. Meningkatkan partisipasi aktif para pihak termasuk masyarakat dalam pemadaman awal kebakaran.

Berikut tahapan-tahapan pelaksanaan Kebijakan Pemerintah Daerah dalam Penanganan

Kebakaran lahan di Kota Palangka Raya sebagai berikut :

1. Kelembagaan :

- Perencanaan pengendalian kebakaran hutan penyususan program dan anggaran.

- Pemetaan kawasan hutan dan lahan yang rawan kebakaran.

- Pengadaan peralatan pemadam kebakaran dan perlengkapan individu.

- Pelatihan dan bintek pengendalian kebakaran hutan dan lahan.

- Pemeliharaan peralatan pemadam dan mesin.

- Rekomendasi kelembagaan.

2. Pencegahan :

- Penyuluhan dan kampanye informasi/sosialisasi.

- Rambu-rambu bahaya kebakaran hutan dan lahan.

- Penegakan hukum dan penyebaran maklumat.

- Rapat koordinasi.

- Apel siaga.

- Patroli

3. Pemadaman :

- Siaga pemadaman

- Koordinasi dan patroli pemadaman

- Mobilisasi anggota regu pemadam, peralatan, dan logistik.

- Kegiatan pemadaman.

- Pemadam gabungan

4. Penanganan Pasca Kebakaran :

- Pengumpulan bahan keterangan.

- Proses penyidikan terhadap pelaku pembakaran.

- Monitoring perkembangan areal bekas kebakaran.

- Evaluasi pengendalian kebakaran.

- Rehabilitasi areal bekas kebakaran

Faktor-faktor penghambat dalam implementasi Kebijakan Pemerintah Daerah dalam penanganan Kebakaran Hutan dan Lahan melalui Dinas Kehutanan dan Perkebunan Kota Palangka Raya adalah sebagai berikut:

1. Kurangnya anggaran yang di berikan oleh Pemerintah Daerah Kota Palangka Raya terhadap penanganan kebakaran lahan di Kota Palangka Raya, dan hal inilah menyebapkan program-program lain yang telah dianggarkan menjadi tertunda dan penanganann kebakaran lahan di Kota Palangka Raya menjadi kurang maksimal setiap tahunnya.

2. Kurangnya partisipasi aktif dari masyarakat dalam ikut serta melaksanakan kebijakan Pemerintah Daerah yang telah dibuat untuk penanganan kebakaran lahan di Wilayah Kota Palangka Raya. 


\section{Saran}

Dengan berdasarkan pada hasil penelitian dan temuan di lapangan, terhadap pelaksanaan Kebijakan Pemerintah Daerah dalam Penanganan Kebakaran Lahan di Kota Palangka Raya. Saran/Rekomendasi dalam penelitian ini mencakup saran/rekomendasi kepada Pemerintah Daerah Kota Palangka Raya, khusunya Dinas Kehutanan dan Perkebunan Kota Palangka Raya, masyarakat Kota Palangka Raya, dan semua pihak yang mempunyai tanggung jawab dalam penanganan permasalahan ini. Saran/rekomendasi sebagai berikut :

1. Pemerintah Daerah Kota Palangka Raya sebaiknya memikirkan kembali agar adanya penambahan anggaran yang lebih untuk pelaksanaan kebijakan-kebijakan yang telah dibuat agar semua kebijakan yang dikeluarkan sesuai dengan anggaran dan hasil yang didapatkan.

2. Dinas Kehutanan dan Perkebunan Kota Palangka Raya jika terjadinya kendala penanganan kebakaran hutan di Kota Palangka Raya hanyalah anggaran maka pihak dinas mempunyai hak mengusulkan penambahan anggaran kepada Pemerintah Daerah, tanpa anggaran semuanya akan terhambat bagi Pemerintah dalam penanganan kebakaran lahan di Kota Palangka Raya.

3. Masyarakat Kota Palangka Raya sebaiknya mendengarkan dan melaksanakan apa yang diinginkan oleh Pemerintah Daerah melalui semua kebijakan-kebijakan yang dikeluarkan selama ini, mengapa demikian kerena diharapkan kerena kerjasama yang benar dan baik dari Pemerintah Daerah bersama masyarakat akan menimbulkan hasil yang baik pula terutama pencegahan dan penanganan kebakaran lahan di Kota Palangka Raya selama ini dan dampak negatif yang kita rasakan selama ini bisa berkurang dan alangkah baiknya bisa tidak terjadi lagi setiap tahunnya akibat kebakaran lahan.

4. Semua Pihak wajib mendukung semua kebijakan yang dikeluarkan oleh Pemerintah Daerah dalam penyelenggaraan Pemerintahan agar kehidupan bermasyarakat bisa terjalin dengan baik dan lancer demi Kota Cantik Palangka Raya.

5. Penelitian selanjutnya :

a. Meneliti lebih jauh seberapa seriusnya Pemerintah Daerah dalam pelaksanaan penanganan kebakaran lahan di Kota Palangka Raya untuk tahun berikutnya.

b. Melakukam penelitian yang lebih mendalam seberapa besar anggaran yang mampu dikeluarkan untuk mengimbangi semua kebijakan-kebijakan Daerah dalam penanganan kebakaran lahan di Kota Palangka Raya untuk tahun selanjutnya.

\section{DAFTAR PUSTAKA}

Agustino, Leo, 2008, Dasar-Dasar Kebijakan Publik, Bandung: Alfabeta.

Alma, Buchari, 2012, Metode dan Teknik Menyusun Proposal Jakarta: Alfabet.

Dinas Perhubungan, Komunikasi, dan Informatika Provinsi Kalimantan Tengah, Dinas Perhubungan, Komunikasi, dan Informatika Kota Palangka Raya, Dinas Kesehatan Kota Palangka Raya, Badan Pusat Statistik.

Himbauan Kepala Dinas Kehutanan dan Perkebunan Kota Palangka Raya Nomor : 522/DKPKP/774/VII/2013 Tentang Larangan Pembakaran Hutan dan Lahan pada musim kemarau tahun 2013.

http://arenakami.blogspot.com/2012/06/implementasi-kebijakan-george-edward.html Akses Tanggal 26 Agustus 2015

http://id.wikipedia.org/wiki/Kota_Palangka_Raya Akses Tanggal 15 Agustus 2014 
http://www.tempo.co/read/news/2014/09/18/206607746/BNPB- Kebakaran-Hutan-dan-lahan Akses Tanggal 15 Agustus 2014

Instruksi Walikota Palangka Raya Nomor : 611 Tahun 2014 Tentang Antisipasi Pencegahan Kebakaran Hutan dan Lahan di Kota Palangka Raya.

Keputusan Kepala Badan Lingkungan Hidup Kota Palangka Raya Nomor 346.1 Tahun 2014 Tentang Pembentukan Tim Posko Penanggulangan Kebakaran Hutan, Lahan, dan Pekarangan Badan Lingkungan Hidup Kota Palangka Raya Tahun 2014.

Keputusan Kepala Dinas Kehutanan dan Perkebunan Kota Palangka Raya Nomor : 386 Tahun 2013 Tentang Pembentukan Tim Pencegahan dan Pengendalian Kebakaran Hutan dan Lahan.

Keputusan Kepala Dinas Kehutanan dan Perkebunan Kota Palangka Raya Nomor : 418.A Tahun 2014 Tentang Pembentukan Tim Pencegahan dan Pengendalian Kebakaran Hutan dan Lahan.

Keputusan Walikota Palangka Raya Nomor 27 Tahun 2014 Tentang Pembentukan Tim Koordinasi Pengendalian Kebakaran Hutan, Lahan, di Wilayah Kota Palangka Raya Tahun 2014.

Keputusan Walikota Palangka Raya Nomor 394 Tahun 2014 Tentang Penetapan Status Tanggap Darurat Bencana Kebakaran Hutan, Lahan, dan Pekarangan serta Kabut Asap di Kota Palangka Raya Tahun 2014.

Keputusan Walikota Palangka Raya Nomor 403 Tahun 2014 Tentang Penyelenggaraan Pos Komando Tanggap Darurat Bencana Kebakaran Hutan, Lahan, dan Pekarangan serta Kabut Asap di Kota Palangka Raya Tahun 2014.

Kesepekatan Bersama antara Kepala Dinas Kehutanan dan Perkebunan Kota Palangka Raya dengan Kepolisian Resor Palangka Raya Tentang Penggelaran PolMas sebagai BinMas Pionir, Nomor : 522.0/546/DKP-KP/01/V/2013 bersama Nomor : B/88/ /V/2013/POLRES.

Moleong, 2005:248. Teknik Pengumpulan Data, Jakarta: Tugas Akhir Program Magister Universitas Indonesia.

Peraturan Daerah Kota Palangka Raya Nomer 07 Tahun 2003 Tentang Pencegahan dan Penanggulangan Kebakaran Hutan dan Lahan di wilayah Kota Palangka Raya.

Peraturan Gubernur Kalimantan Tengah Nomor 15 Tahun 2010 Tentang Perubahan Atas Peraturan Gubernur Kalimantan Tengah Nomor 52 Tahun 2008 Tentang Pedoman Pembukaan Lahan dan Pekarangan Bagi Masyarakat di Kalimantan Tengah.

Peraturan Gubernur Kalimantan Tengah Nomor 52 Tahun 2008 Tentang Pedoman Pembukaan Lahan dan Pekarangan Bagi Masyarakat di Kalimantan Tengah.

Peraturan Pemerintah Nomor 04 Tahun 2001 Tentang Pengendalian Kebakaran Hutan dan Lahan.

Peraturan Pemerintah Nomor 41 Tahun 1999 Tentang Pengendalian Pencemaran Udara.

Prosedur Tetap Operasional (protap) Pengendalian Kebakaran Hutan dan Lahan di Kota Palangka Raya.

Saman, Mukhtar, 2004, Pengantar Metodologi Penelitian Sosial, Banjarmasin: Fisip Unlam.

Satori, Djam'an, 2012, Metode Penelitian Kualitatif, Bandung: Pusaka Lima. 
Siagian, Sondang P. 2011, Sistem Informasi Manajemen, Jakarta: Bumi Aksara.

Sukarna, 1992, Dasar-Dasar Manajemen, Bandung: Mandar Maju.

Surat Gubernur Kalimantan Tengah Nomor : 360/317.1/BPBD/2014 Tanggal 30 Mei 2014 Tentang Antisipasi Penanggulangan Bencana Asap Akibat Kebakaran Hutan dan Lahan.

Undang-Undang Dasar Republik Indonesia 1945.

Undang-Undang Nomor 01 Tahun 2004 Tentang Kehutanan.

Undang-Undang Nomor 23 Tahun 1997 Tentang Pengelolaan Lingkungan Hidup.

Undang-Undang Otonomi Daerah Nomor 23 Tahun 2014 Tentang Pemerintahan Daerah.

Undang-Undang Republik Indonesia Nomor 18 Tahun 2013 Tentang Pencegahan dan Pemberantasan Hutan. 